УДК 159.923 .2

DOI: https://doi.org/10.33120/ssj.vi46(49).162

\author{
Петровська Інга Ростиславівна \\ кандидат технічних наук, доцент, \\ доцент кафедри психології, \\ Львівський національний університет імені Івана Франка, \\ м. Львів, Україна \\ ORCID ID 0000-0001-7544-945X \\ petrovin55@gmail.com
}

\title{
ТРИРІВНЕВА СТРУКТУРА ГРОМАДЯНСЬКОЇ ІДЕНТИЧНОСТІ ОСОБИСТОСТІ
}

Метою статті $є$ теоретичне обгрунтування трирівневої структури громадянської ідентичності особистості. Теоретико-методологічною основою дослідження стали положення і принципи теорії соціальної ідентичності та соціальної самокатегоризації (Г. Теджфел, Дж. Тернер), концепції організаційної ідентичності (С. Альберт, Б. Ешворт, Дж. Даттон) та рольові теорії (Е. Берн, Е. Гоффман). Запропоновано розглядати громадянську ідентичність як різновид організаційної ідентичності, що функціонує на трьох рівнях: інституціональному («громадянин - держава»), спільнотному («громадянин - спільнота громадян») та індивідуальному («громадянин - Я»). Обгрунтовано, що інституціональний рівень громадянської ідентичності передбачає включеність особистості в організаційне середовище держави: когнітивну (розуміння нормативного поля держави $\mathrm{i}$ реальної практики організаційної взаємодії в ньому), ціннісну (соціальна перцепція аксіологічного поля держави, термінальних цінностей державності загалом і конкретної держави зокрема), емоційну (переживання, пов'язані 3 відносинами 3 державою як організацією) та поведінкову (реалізація громадянської поведінки). Громадянська ідентичність на спільнотному рівні передбачає афіліацію зі співгромадянами (фактичне прийняття їх як інгрупи, виробленого ними громадянського менталітету; схоже розуміння всіх подій та процесів організаційного середовища держави, що полегшує та інтенсифікує комунікацію між співгромадянами незалежно від їхньої етнічної належності). Спільний досвід переживання типових проблем (від побутових до державно-політичних) сам по собі ще не гарантує згуртованості, взаємопідтримки чи позитивної оцінки співгромадян, але закладає основи громадянської солідарності завдяки спільній цінності та значущості цього досвіду. Індивідуальний рівень громадянської ідентичності передбачає самоідентифікацію з роллю громадянина (у контексті ігрових та сценарних взаємодій з державними інституціями та співгромадянами). Особистість може різною мірою ідентифікуватися зі своєю роллю громадянина, добре або погано "знати свою роль”, але в кожному разі роль громадянина стає частиною ії рольового репертуару. Програвання ролі громадянина може зумовлювати як відкриті конструктивні стосунки 3 державою, так і (частіше) стосунки сурогатні, що виявляється в різноманітних психологічних іграх-маніпуляціях та деструктивних сценаріях. Кожен зі згаданих рівнів громадянської ідентичності може бути розвинутим різною мірою. Домінування одного з рівнів свідчить про певну типовість виявів громадянськості, отож перспективу подальших досліджень вбачаємо в розробленні типології громадянської ідентичності особистості та конструюванні відповідного дослідницького інструментарію.

Ключові слова: громадянська ідентичність; держава; спільнота громадян; рівні; афіліація; менталітет; роль; ігрова взаємодія; організаційна ідентичність. 


\title{
THREE-LEVEL STRUCTURE OF CIVIC IDENTITY
}

\author{
Inha R. Petrovska \\ Ph.D. in Technical Sciences, Docent, \\ Associate Professor of the Department of Psychology, \\ Ivan Franko National University of Lviv, \\ Lviv, Ukraine \\ ORCID ID 0000-0001-7544-945X \\ petrovin55@gmail.com
}

The article is dedicated to the theoretical substantiation of the three-level structure of the civic identity of an individual. The theoretical and methodological basis of the study were the theories of social identity and social self-categorization (H. Tajfel, J. Turner), the concept of organizational identity (S. Albert, B. Ashforth, J. Dutton), and role theories (E. Berne, E. Goffman). It is proposed to consider civic identity as a kind of organizational identity that operates on three levels: institutional ("citizen-state"), community ("citizen-community of citizens"), and individual ("citizenI"). It is proven that the institutional level of civic identity presupposes the inclusion of the individual in the organizational environment of the state: cognitive (understanding of the normative field of the state and the real practice of organizational interaction in it), value (social perception of the axiological field of the state, the terminal values of statehood in general and a specific state in particular), emotional (experiences associated with relations with the state as an organization), and behavioral one (realization of civic behavior). Civic identity at the community (group) level involves affiliation with co-citizens (actual acceptance of them as in-group; civic mentality developed by them; similar understanding of all events and processes of the organizational environment of the state, which facilitates and intensifies communication between citizens regardless of their ethnicity). The common experience of facing typical problems (from domestic to political) itself does not lead to cohesion, mutual support, or positive assessment of co-citizens, but it puts the foundation for civic solidarity due to the common value and significance of this experience. The individual level of civic identity presupposes self-identification with the role of a citizen (in the context of role and script interactions with state institutions and fellow citizens). An individual may identify ownself with his/her role as a citizen at varying degrees, may "know" it well or not, but in each case, the role of the citizen becomes part of his/her role repertoire. Playing the role of a citizen can result in both open constructive and (more often) surrogate relations with the state, which may lead to various psychological games-manipulations and destructive scenarios. Each of these levels of civic identity can be developed in a different manner. The dominance of one of the levels carries certain typicality of manifestations of citizenship, so we see the prospect of further research in the development of a typology of the civic identity of an individual, and designing appropriate research tools.

Keywords: civic identity; state; community of citizens; levels; affiliation; mentality; role; role interaction; organizational identity.

Постановка проблеми. Психологічне розуміння i психологічний аналіз громадянської ідентичності мають виражену специфіку порівняно $з$ іiі розумінням та аналізом у суміжних науках, таких як право, політологія, соціологія. Для названих нами наук громадянська ідентичність зводиться до встановлення формальної належності особи до держави як іiі громадянина. Для політологічного чи правового аналізу не завжди важливо, якою є історична пам'ять спільноти щодо виборювання/реалізації державності, які в неї домінантні стереотипи, атитюди чи експектації щодо громадянства.

Однак громадянство може бути усвідомленим, але не акцептованим або не до кінця інтеріоризованим самим громадянином, унаслідок чого зміна громадянства не спричинюється до жодних психологічних проблем. Публічна декларація громадянства i фактична наявність громадянської ідентичності як особистісної підструктури часто не збігаються. Особливо це помітно в державах 3 нетривалим досвідом державності. Нова громадянська ідентичність не виникає миттєво, у момент проголошення незалежності. Тому вона може бути аморфною, частково сформованою, девіантною. Відповідно, у складний для 
держави час громадяни можуть легко відмовлятися від свого громадянства - як шляхом еміграції, так і шляхом “легального” голосування за передачу іншій державі території, на якій вони мешкають. Ситуація аналогічна проблемі плинності кадрів в організації, коли працівники лояльні лише формально, часто звільняються, а часом співпрацюють 3 організаціями-конкурентами.

Це свідчить про необхідність пошуку досконаліших інструментів вимірювання громадянської ідентичності, ніж проста декларація громадянських диспозицій в опитуванні. Розроблення відповідного дослідницького інструментарію неможливе без заглиблення в онтологічну сутність феномену громадянської ідентичності.

Аналіз останніх досліджень і публікацій, виокремлення нерозв'язаних частин загальної проблеми. Громадянську ідентичність часто плутають 3 національною ідентичністю, використовуючи ці поняття як синоніми, розглядаючи одну як підструктуру іншої (Hristova, \& Cekik, 2013; Pakulski, \& Tranter, 2000; Гримич, 2009). Останнім часом у науковому дискурсі також спостерігається тенденція не розмежовувати поняття національної, державної та громадянської ідентичностей, коли йдеться про ідентичність національно-громадянську (Дробижева, 2008; Бушуев, \& Титов, 2011) чи державногромадянську (Арутюнова, 2007). Щоб розкрити сутність громадянської ідентичності та виокремити адекватні операціональні критерії іiі вирізнення з-поміж інших, слід зіставити ії 3 етнічною та національною ідентичностями, виявити основні відмінності цих ідентичностей, які в структурі особистості частково перетинаються (Хазратова, 2015; Петровська, 2016; Голоденко, 2013).

Громадянська ідентичність передбачає самовизначення як громадянина незалежно від етнічного коріння та національного походження. Громадян як членів організації (держави) об’єднують спільні організаційні цінності, а також спільність проблем, обмежень i можливостей конкретного організаційного середовища держави. Тому громадянська ідентичність, на відміну від національної, $є$ абстрагованою від етнічного походження i етнонаціональної культури. Наприклад, етнічний китаєць - громадянин США - може мати громадянську ідентичність американця (солідарність з іншими американцями, включеність у політичне життя Америки, розуміння проблем сучасних Сполучених Штатів), але його етнонаціональна ідентичність може водночас залишатися китайською (вірність китайським національним традиціям, цінностям, володіння мовою, прихильність до етнічної кухні та одягу тощо). Слід зазначити: національна ідентичність означає, що людина занурена в контекст власної національної культури (щонайменше є носієм мови і етнонаціональної культури). У денаціоналізованих суспільствах далеко не всі $є$ носіями національної культури, проте більшість є носіями громадянської культури і громадянської ідентичності.

Отже, порівнюючи етнонаціональну і громадянську ідентичності, можемо зазначити такі принципові, на наш погляд, відмінності:

- етнонаціональна ідентичність спирається на біосоціальне підгрунтя, пов'язане 3 генетичним корінням нації, що втілюється як у певних антропоморфних характеристиках, так і в культурі та мові. Громадянська ідентичність за своєю суттю не $\epsilon$ прив'язаною до біосоціальної основи; вона є утворенням організаційної психіки;

- етнонаціональна ідентичність передбачає неформальні стосунки з власною групою (етнічною або національною), а громадянська - передусім формальні. Громадянська ідентичність передбачає належність не лише до групи, а передусім до організації (держави), відповідно, чіткіше визначені роль і статус, права та обов'язки особи як громадянина. Зі свого боку, держава має обов'язки щодо громадянина, а також визначені цілі та моделі, яким вона підпорядковує розвиток суспільства;

- природа етнонаціональної ідентичності є більш конкретною через її прив’язаність до етнічних i територіально-географічних характеристик; природа громадянської ідентичності натомість більш абстрактна. Держава як організація більшою мірою абстрагована як від конкретного “етнічного субстрату” (різні етноси і нації в складі держави), так i, певною мірою, від території (держави іноді зазнають змін своїх кордонів). 
Відповідно, відмінними мають бути емпіричні індикатори кожної 3 двох розглянутих ідентичностей особистості.

Мета статті - теоретичне обгрунтування трирівневої структури громадянської ідентичності особистості та способів операціоналізації громадянської ідентичності на різних рівнях ії функціонування.

Виклад основного матеріалу дослідження. Громадянську ідентичність ми розглядаємо як різновид організаційної ідентичності (Петровська, 2018), яка полягає в самовизначенні в організаційному середовищі держави, а також самоідентифікації з роллю громадянина в контексті ігрових і сценарних взаємодій з державними інституціями та співгромадянами і є основним психологічним регулятором громадянської поведінки. Самовизначення особистості в організаційному середовищі держави зумовлене необхідністю включення в нього задля задоволення потреб особистості в самореалізації (соціальному визнанні), афіліації, безпеці, а також у сенсі. Самовизначення відбувається за рахунок самокатегоризації, що є сутнісним процесом у формуванні ідентичності; іiі уникнення призводить до аморфності ідентичності, що унеможливлює самореалізацію.

Організаційне середовище держави істотно репрезентоване в житті особистості 3 дитинства. Прикладом тут може бути не лише вивчення державної символіки та патріотичних пісень в освітніх установах. Держава оголошує карантин і обмежує можливості пересування особи; вона визначає стандарти надання медичної допомоги; взаємодія між людьми (зокрема й у сім'ї) регламентується законами держави. Дитина стикається з фактами залежності батьків та прабатьків-пенсіонерів від державних виплат; батьки-бізнесмени залежать від державно-фінансових організацій, що контролюють їхній бізнес, тощо.

Унаслідок занурення в організаційне середовище держави особистість поступово напрацьовує релевантну ій організаційну ідентичність. Образно кажучи, ця ідентичність відповідає на питання “хто я в цій системі? Ким хочу і ким можу бути в цій організації?”. Запитання і відповіді не завжди є усвідомленими, але вони несуть змісти щодо можливостей виживання і самореалізації в цій організаційній реальності, щодо прийняття цінностей $\mathrm{i}$ правил (як явних, так і неявних) цієї організації.

Слід наголосити, що згадане вище самовизначення і зумовлена ним ідентичність регулюють організаційну поведінку особистості - громадянську поведінку. Ми застосовуємо термін “громадянська поведінка" не в сенсі “правильних", соціально схвалюваних дій щодо держави, а в науково-психологічному розумінні - як будь-яку поведінку особи щодо держави; як дії особи в статусі громадянина. Наприклад: як сплата, так і несплата податків державі - громадянська поведінка; участь чи неучасть у виборах як виборця - громадянська поведінка; зміна громадянства чи перебування далі в статусі громадянина тієї самої держави - громадянська поведінка.

3 огляду на те, що організаційна ідентичність завжди регулює організаційну поведінку, можемо стверджувати, що громадянська ідентичність аналогічно регулює громадянську поведінку. Громадянська ідентичність функціонує на різних рівнях, а саме: інституиіональному (відповідає стосункам “громадянин - держава»), спільнотному (груповому) (відповідає стосункам “громадянин - спільнота громадян») та індивідуальному («громадянин - Я»).

На інституиіональному рівні громадянська ідентичність грунтується на осмисленні себе в організаційному середовищі держави, зіставленні себе (як громадянина) з державою (як організацією). Організаційне середовище держави - це результат регламентації організацією взаємодії між людьми (iі формальної сторони), соціально-психологічне середовище, що характеризується сукупністю певних констант організаційної взаємодії. Організаційне середовище держави має щонаймеше два виміри: ієрархічний (державна влада, будова якої є ієрархічною) і нормативний (політико-правові відносини).

Активність особистості в організаційному середовищі держави зумовлена іiі психологічними потребами, зокрема в соціальній самореалізації, у безпеці та сенсі життя. Ця активність регламентується законами і передбачає контакт з представниками держави. 
Досвід цієї активності зумовлює включеність особистості в організаційне середовище держави - ціннісну, емоційну, когнітивну та поведінкову. Ціннісна включеність означає соціальну перцепцію аксіологічного поля держави, термінальних цінностей державності загалом і конкретної держави зокрема; когнітивна - розуміння нормативного поля держави і реальної практики організаційної взаємодії в ньому; емоційна - емоційні переживання, пов'язані з відносинами з державою як організацією; поведінкова - реалізацію громадянської поведінки.

Несформована громадянська ідентичність мала б виявити себе невключеністю або низьким рівнем такої включеності.

Громадянська ідентичність на спільнотному (груповому) рівні передбачає афіліацію зі співгромадянами. Спільний досвід переживання типових проблем (від побутових до державно-політичних) формує специфічний феномен - консорціум громадян (відрізняється від громадянського суспільства, якому відповідає досить високий рівень розвитку громадянськості). У певному сенсі спільноту громадян можна порівняти з територіальною спільнотою, наприклад зі спільнотою мешканців багатоквартирного будинку. Різні за віком та етнічним походженням, вони об'єднані спільною ситуацією проживання в будинку і мікрорайоні: у них однакові комунальні проблеми, екологічна ситуація, управлінська взаємодія (ОСББ або ЖЕК).

Тривалий спільний досвід подолання типових проблем сам по собі не спричиняє згуртованості, взаємопідтримки чи позитивної оцінки співгромадян, але закладає основи громадянської солідарності завдяки спільній цінності та значущості цього досвіду. Особливим утворенням, що об'єднує громадян, є громадянський менталітет - специфічне для громадян різних держав світосприйняття, сфокусоване передусім на сприйнятті організаційної реальності власної держави, квінтесенція життєвого досвіду багатьох поколінь ii громадян. Виходить, бути громадянином психологічно - це відчувати себе членом цієї громадянської спільноти, бути носієм громадянської ментальності.

Емпіричне вимірювання рівня громадянської ідентичності полягає у визначенні рівня афіліації із співгромадянами. Індикаторами будуть фактичне прийняття їх як інгрупи та виробленого ними громадянського менталітету; схоже розуміння та осмислення всіх подій i процесів організаційного середовища держави, що полегшує та інтенсифікує комунікацію між співгромадянами незалежно від їхньої етнічної належності.

Наступний рівень функціонування громадянської ідентичності - індивідуальний. Якщо громадянство означає певний формальний статус, права та обов'язки, то з цього погляду особа отримує певну роль - роль громадянина, яку має грати протягом життя. У такому разі можна інтерпретувати громадянську ідентичність на індивідуальному рівні в контексті поширених у соціальній психології рольових теорій Е. Берна, Е. Гоффмана та ін. Поняття ролі в цих теоріях передбачає незбіг удаваного з тим, що є реально. Водночас стверджується, що в процесі постійної гри ролі стають реальністю, а “справжність" поступово втрачається («маска приростає до обличчя" - часте удавання якихось станів чи процесів зумовлює їх справжнє переживання). Аналогічно, особистість може різною мірою ідентифікуватися зі своєю роллю громадянина, добре або погано “знати свою роль”, але в кожному разі роль громадянина стає частиною їі рольового репертуару. Згідно з рольовими теоріями, наявність ролі та іiі прийняття означають наявність гри, включення особистості в неї. Роль Громадянина означає, що $є$ також роль Держави. Відповідно, існують також ролі Співгромадян. Ідучи за цією логікою, наявність ролей і гри означає, що є особистісний (організаційний) сценарій.

У бернівському розумінні цієї термінології роль, гра i сценарій $є$ зазвичай деструктивними утвореннями, хоча роблять важливу справу для особистості - компенсують страх справжньої близькості та щирості в стосунках. Тому найчастіше домінують сурогатні стосунки.

На нашу думку, аналогічною є ситуація у стосунках особистості й держави, а також інших громадян. Особистість вступає в досить типові ігри з державою, де вона грає роль 
Громадянина, а також проєкує на державу та співгромадян інші ролі. Основною ознакою психологічної гри, відмінної від щирої взаємодії, є наявність прихованої вигоди, маніпуляції, на якій ці стосунки грунтуються. Найчастіше такою “вигодою” $\epsilon$ відмова від відповідальності. Про відмову від відповідальності як основну проблему стосунків особистості з державою писав ще К. Г. Юнг (1992).

Спробуймо відтак описати деякі типові ігри та сценарії, поширені, на наш погляд, серед українських громадян.

Перший типовий варіант гри можна назвати "Переслідування" - вона аналогічна описаній Е. Берном грі “Алкоголік” (Берн, 2008). Головна роль - це Громадянин (Жертва), їй відповідає роль Держави-Переслідувача. Держава переслідує Жертву, а саме: душить непомірними цінами на комунальні послуги; не надає помешкання, а прописки вимагає; заганяє бізнесмена (Громадянина-Жертву) в тінь, у гріх несплати податків і в кримінал. Жертва потерпає, залишається на все життя незаможною і правопорушною, що дає ій такі психологічні вигоди: право скаржитися на державу й сподіватися на підтримку (Жертва скаржиться усім; це окрема гра “Яка у нас жахлива держава!”, в яку можуть грати всі співгромадяни, від жебраків до олігархів); моральне виправдання правопорушень («У нас чесним шляхом не заробиш»); а також право переадресувати відповідальність державі («Я маленька людина, від мене нічого не залежить»). Жертва залишається пасивною, не бере на себе відповідальності, не ініціює змін, але в контексті громадянської ментальності отримує увагу, підтримку і соціальне схвалення.

У деяких модифікаціях цієї гри певні ролі розігруються також співгромадянами: роль Рятівника (політика, який ініціює рятівні реформи, але все зводиться до балачок), Підбурювача (який виводить Жертв на черговий Майдан) і т. ін.

Ще однією типовою грою є гра, яку можна було б назвати “Чекай, я зараз реформуюся”. Громадяни критикують державу, щораз гостріше, демонструють ій недовіру. Тоді на рівні держави черговий раз ініціюються реформи. Громадянин не вірить у реформи, його переконують, а потім вкотре ошукують. Тоді ситуація повертається до початкового протистояння. Мета маніпуляцій з боку держави - збереження системи, яка мала ось-ось розвалитися; психологічне маніпулювання з боку громадянина полягає в тому, що він таки не бере на себе відповідальність за стан справ у державі, даючи себе ошукувати знову i знову.

Отже, програвання ролі Громадянина може зумовлювати як відкриті конструктивні стосунки $з$ державою, так і (частіше) стосунки сурогатні, що виявляється в різноманітних психологічних іграх-маніпуляціях та деструктивних сценаріях. Тому діагностика громадянської ідентичності мала б включати в себе виявлення можливих деструктивних психологічних ігор з такими персонажами, як Держава-Переслідувач і Співгромадяни.

Кожен зі згаданих рівнів громадянської ідентичності може бути по-різному розвинутим. Домінування одного 3 рівнів свідчить про певну типовість виявів громадянськості.

Варто зазначити, що основні функції громадянської ідентичності також відповідають різним рівням іï функціонування:

$>$ інституціональному:

○ адаптаційна функція (пристосування до організаційного середовища держави для забезпечення можливості функціонування в ньому задля задоволення своїх потреб (зокрема в соціальній самореалізації - держава продукує організаційний простір, у якому розгортається соціальна самореалізація кожного громадянина);

$>$ спільнотному:

○ інтеграційна/консолідащійна функція (формування почуття “Ми”, що поєднує людину 3 громадянською спільнотою; зближення і зв'язок $з$ іншими громадянами; об’єднання і збереження єдності громадян, зокрема і у виявах громадянської конформності); 
○ захисна функція (реалізація афіліативної потреби, що дає змогу долати страх i тривогу в умовах, що змінюються; зменшує почуття невизначеності за рахунок усвідомлення зв'язку і подібності умов організації життя з іншими громадянами в державі; забезпечує почуття персональної безпеки та соціального захисту);

$>$ індивідуальному:

- функція забезпечення самоповаги і сочіальної цінності (ідентифікація особи 3 громадянином держави, яка має високий міжнародний статус і визнання, сприяє підвищенню рівня iї самоповаги; успіхи держави в зовнішній та внутрішній політиці, досягнення та перемоги співгромадян у різних сферах викликають позитивні громадянські почуття (гордість, прихильність) і сприяють позитивному самоставленню, підвищенню самооцінки особи як такої, що належить до успішної високостатусної групи); водночас самоповага може підтримуватися і в процесі деструктивних ігор, 3 проєкуванням на державу відповідних ролей;

○ регулятивна функція громадянської ідентичності полягає в регулюванні різних видів громадянської поведінки.

Висновки та перспективи подалыших досліджень. Розробляючи дослідницький інструментарій громадянської ідентичності, доцільно враховувати особливості когнітивної, ціннісної, емоційної та поведінкової включеності особи в організаційне середовище держави (інституційний рівень); рівень афіліації зі спільнотою громадян, незалежно від ставлення до них (схвалення чи осуд) варто оцінювати фактичне прийняття їх як інгрупи (спільнотний рівень); значущість громадянської ідентичності (висока або середня позиція цієї ідентичності в суб'єктивній ієрархії інших ідентичностей особистості), а також особливості засвоєного рольового репертуару громадянина, типові для особи ігрові та сценарні транзакції 3 державою та співгромадянами (індивідуальний рівень). Кожен зі згаданих рівнів громадянської ідентичності може бути розвинутим різною мірою. Домінування одного 3 рівнів свідчить про певну типовість виявів громадянськості, отож перспективу подальших досліджень вбачаємо в теоретичному та емпіричному виявленні типології громадянської ідентичності особистості.

\section{Список використаних джерел}

Арутюнова, Е. М. (2007). Формирование государственно-гражданской идентичности молодежи (Автореф. дис. канд. социол. наук). Российский университет дружбы народов, Москва.

Берн, Э. (2008). За пределами игр и сценариев. Минск: Попурри.

Бушуев, В. В., \& Титов, В.В.(2011). Национально-государственная идентичность в современном мире и роль исторической политики в ее формировании (теоретико-методологический анализ). Вестник “История и политология", 4, 77-93.

Голоденко, О. Ю. (2013). Теоретичні та емпіричні можливості вивчення громадянської ідентичності. Вісник Львівського університету. Серія соиіологічна, 7, 60-68.

Гримич, М. (2009). Ідентичність, етнічність, етнічна ідентичність: терміни та поняття. Етнічна історія народів Свропи, 28, 46-54.

Дробижева, Л. М. (2008). Национально-гражданская и этническая идентичность: проблемь позитивной совместимости. В Россия реформирующаяся (вып. 7, с. 214-228). Москва: Институт социологии РАН.

Петровська, I. Р. (2018). Громадянська ідентичність як різновид організаційної ідентичності. Проблеми сучасної психологї̈, 39, 244-257.

Петровська, І. Р. (2016). Відмінності громадянської ідентичності від етнічної та національної ідентичностей. Актуальні питання сучасної психологї̈. Матеріали III Міжнародної науковопрактичної конференції, м. Дніпропетровськ, 7-8 жовтня, 2016 р. (с. 72-76). Херсон: Гельветика.

Хазратова, Н. В. (2015). Громадянська ідентичність у структурі особистісних ідентичностей. Проблеми політичної психології. 2 (16), 112-125.

Юнг, К. Г. (1992). Современность и будущее. Минск: Университетское. 
Hristova, L. \& Cekik, A. (2013). Between the ethnic and the civic identity - on the perceptions of the student population in the Republic of Macedonia. New Balkan Politics, 13, 45-70.

Pakulski, J. \& Tranter, B. (2000). Civic, national and denizen identity in Australia. Journal of Sociology, 36 (2), 205-222.

\section{References}

Arutyunova, Ye. M. (2007). Formirovaniye gosudarstvenno-grazhdanskoy identichnosti molodezhi [Formation of the state-civic identity of youth]. (Extended abstract of $\mathrm{PhD}$ dissertation, Sociological sciences). Rossiyskiy universitet druzhby narodov, Moscow. (in Russian)

Bern, E. (2008). Beyond games and scenarios. Minsk: Popurri. (in Russian)

Bushuyev, V. V. \& Titov, V. V. (2011). Natsionalno-gosudarstvennaya identichnost v sovremennom mire i rol istoricheskoy politiki $\mathrm{v}$ yeye formirovanii (teoretiko-metodologicheskiy analiz) [National-state identity in the modern world and the role of historical politics in its formation (theoretical and methodological analysis)]. Vestnik "Istoriya i politologiya", 4, 77-93. (in Russian)

Drobizheva, L. M. (2008). Natsionalno-grazhdanskaya i etnicheskaya identichnost: problemy pozitivnoy sovmestimosti [National, civic and ethnic identity: problems of positive compatibility]. In Rossiya reformiruyushchayasya (Vol. 7, pp. 214-228). Moscow: Institut sotsiologii RAN. (in Russian)

Holodenko, O. Yu. (2013). Teoretychni ta empirychni mozhlyvosti vyvchennia hromadianskoi identychnosti [Theoretical and empirical possibilities of studying civic identity]. Visnyk Lvivskoho universytetu. Seriia sotsiolohichna, 7, 60-68. (in Ukrainian)

Hristova, L. \& Cekik, A. (2013). Between the ethnic and the civic identity - on the perceptions of the student population in the Republic of Macedonia. New Balkan Politics, 13, 45-70. (in English)

Hrymych, M. (2009). Identychnist, etnichnist, etnichna identychnist: terminy ta ponyattya [Identity, ethnicity, ethnic identity: terms and concepts.]. Etnichna istoriia narodiv Yevropy, 28, 46-54. (in Ukrainian)

Khazratova, N. V. (2015). Hromadianska identychnist u strukturi osobystisnykh identychnostei [Civic identity in the structure of personal identities]. Problemy politychnoi psykholohii, 2 (16), 112-125. (in Ukrainian)

Pakulski, J. \& Tranter, B. (2000). Civic, national and denizen identity in Australia. Journal of Sociology, 36 (2), 205-222. (in English)

Petrovska, I. R. (2018). Hromadianska identychnist yak riznovyd orhanizatsiinoi identychnosti [Civic identity as a kind of organizational identity]. Problemy suchasnoi psykholohii, 39, 244-257. (in Ukrainian)

Petrovska, I. R. (2016). Vidminnosti hromadianskoi identychnosti vid etnichnoi ta natsionalnoi identychnostei [Differences between civic. ethnic and national identities]. Aktualni pytannia suchasnoi psykholohii. (Proceedings of the Conference, Dnipropetrovsk, October 7-8, 2016) (pp. 72-76). Kherson: Helvetyka. (in Ukrainian)

Yung, K. G. (1992). Sovremennost $i$ budushcheye [Modernity and the future]. Minsk: Universitetskoye. (in Russian) 